\title{
Purification and amino acid sequence of vasoactive intestinal peptide, peptide histidine isoleucinamide (1-27) and secretin from the small intestine of guinea pig
}

\author{
Louis Buscail, Annick Cauvin, Philippe Gourlet, Denis Gossen, Philippe De Neef, \\ Jean Rathé, Patrick Robberecht, Marie-Claire Vandermeers-Piret, André Vandermeers \\ and Jean Christophe \\ Department of Biochemistry and Nutrition, Medical School, Université Libre de Bruxelles, Brussels (Belgitum)
}

(Received 6 November 1989)

Key words: Vasoactive intestinal peptide; Peptide histidine isoleucinamide; Neuropeptide; Secretin; Sequence analysis; (Guinea pig)

The neuropeptides vasoactive intestinal peptide (VIP) and peptide histidine isoleucinamide (1-27) (PHI) and the hormone secretin were purified from the small intestine of guinea pig, being detected by radioimmunoassay and radioreceptor assay throughout six to seven chromatographic steps. After elution on a reverse-phase C18 column, the three peptides were separated on a Fractogel column. After cation-exchange chromatography of each peptide on Mono $\mathrm{S}$, the final steps were performed using a reverse-phase RP8-e column. Guinea pig PHI differed from porcine PHI in having Tyr and Arg residues instead of Phe and Lys in, respectively, position 10 and 20. We confirmed the original sequence of guinea pig VIP previously documented (with Leu ${ }^{5}, \mathrm{Thr}^{9}, \mathrm{Met}^{19}$ and $\mathrm{Val}^{26}$ ). We also established the similarity of the primary structure of guinea pig secretin with that of porcine and bovine.

\section{Introduction}

The amino acid sequence of porcine [1], bovine [2], dog [3], guinea pig [4], rat [5,6], rabbit [7] and human $[6,8]$ vasoactive intestinal peptide (VIP) has already been established. The primary structure of VIP, with the obvious exception of guinea pig, is identical in the six other mammals. The amino acid sequence of porcine [9], bovine [10], rat [6,11] and human [12] peptide histidine isoleucinamide (1-27) ( $\mathrm{PHI})$ has also been determined and can differ in four positions: 10, 12, 17 and 27. VIP and PHI are cosynthesized and then coreleased from the same nerve endings [13]. Both neuropeptides are likely to act in target organs on the same receptors [14], but these receptors show higher affinity for VIP than for PHI in almost all tissues studied so far.

The sequence of secretin of porcine [15], bovine [16], dog [17], rat [18] and human [19] origin has also been

\footnotetext{
Abbreviations: PHI, peptide histidine isoleucinamide (1-27); PTH, phenylthiohydantoin; VIP, vasoactive intestinal peptide; IR, immunoreactive.

Correspondence: J. Christophe, Department of Biochemistry and Nutrition, Medical School, Université Libre de Bruxelles, Boulevard of Waterloo 115, B-1000 Brussels, Belgium.
}

obtained, and this hormone shows significant species differences.

As the guinea pig is currently used in physiological studies, we found it of interest to purify to homogeneity, as rapidly and efficiently as possible, enough VIP, PHI and secretin from its small intestine in order to document the unknown amino acid sequence of PHI and secretin, and to confirm the highly original sequence of VIP.

\section{Materials and Methods}

\section{Tissue preparation}

Small intestines were removed from duodenum to caecum from 20 male adult Dunkin-Hartley guinea pigs and rinsed with $0.15 \mathrm{M} \mathrm{NaCl}$ at room temperature. The material collected $(220 \mathrm{~g})$ was frozen in liquid nitrogen and stored at $-70^{\circ} \mathrm{C}$.

\section{Materials}

Rabbit antisera $\mathrm{SN} 14$ and $\mathrm{AC} 24$ raised against, respectively, synthetic porcine secretin and porcine PHI were obtained as previously described $[11,18]$. Normal rabbit serum and sheep anti-rabbit immunoglobulins were purchased from the Laboratory of Hormonology (Marloie, Belgium), synthetic porcine VIP and PHI 
were kindly given by Dr. D.H. Coy (Tulane University, New Orleans, LA, U.S.A.), and synthetic porcine secretin was provided by Dr. W. König (Hoechst Aktiengesellschaft, Frankfurt/Main, F.R.G.).

The tracers used were $\left[{ }^{125}\right.$ I]Data-secretin (Fluka, Buchs, Switzerland), $\left[{ }^{125} \mathrm{I}\right] \mathrm{VIP}$ and $\left[{ }^{125} \mathrm{I}\right] \mathrm{PHI}$, iodinated as previously described $[14,18,20]$. [ $\left.{ }^{125} \mathrm{I}\right]$ Iodine carrierfree (IMS 300) was purchased from Amersham International (U.K.).

\section{VIP, PHI, and secretin detection}

Radioimmunoassays were used for detection during the first steps of PHI isolation and for secretin during the entire purification procedure, as detailed elsewhere $[10,11,18]$. The radioreceptor assay, using $\left[{ }^{125} \mathrm{I}\right] \mathrm{VIP}$ as tracer and rat hepatic membranes as source of VIP/PHI receptors, was utilized for VIP and PHI detection during the final steps, and performed as previously described $[14,20]$. This method allowed a rapid detection, but was not used for quantitative evaluation of the neuropeptidic material.

\section{Purification procedure}

Small intestines were boiled in $2 \mathrm{ml}$ of water for 10 min, homogenized with an Ultra-Turrax, cooled at $4^{\circ} \mathrm{C}$, and acidified with acetic acid to a $1.0 \mathrm{M}$ final concentration. Peptides present in the $15000 \times g$ supernatant were adsorbed on a reverse-phase $15 \times 1.5 \mathrm{~cm}$ Bulk C18 column (Waters, Milford, MA, U.S.A.) and eluted with $50 \% \mathrm{CH}_{3} \mathrm{CN}$ in $10 \mathrm{mM} \mathrm{HCl}$ at a flow rate of $3 \mathrm{ml} / \mathrm{min}$. Two successive runs on this preparative column allowed the extract to be concentrated to $60 \mathrm{ml}$, which was divided into 10 aliquots. After $\mathrm{CH}_{3} \mathrm{CN}$ evaporation, the eluate was lyophilized, and each aliquot was then successively applied on a size fractionation Fractogel column $(90 \times 1.6 \mathrm{~cm})$ made of the superposition of Fractogel TSK HW $40 \mathrm{~S}(50 \mathrm{~cm})$ and TSK HW50S $(40 \mathrm{~cm})$ (Merck, Darmstadt, F.R.G.) equilibrated and eluted with a $60 \mathrm{mM}$ phosphate buffer $(\mathrm{pH} 7.2)$ containing $0.3 \%$ bovine serum albumin (w/v), $0.02 \%$ Tween 20 $(\mathrm{v} / \mathrm{v})$ and $0.1 \% \mathrm{NaN}_{3}(\mathrm{w} / \mathrm{v})$ at a flow rate of $8.8 \mathrm{ml} / \mathrm{h}$. PHI-IR eluted in two distinct peaks of different $M_{\mathrm{f}}$ values (Fig. 1, upper panel). Secretin-IR eluted in a single peak (Fig. 1, middle panel), at a position distinct from the PHI peaks. A separate VIP material was identified by radioreceptor assay, in a position differing from the minor and major PHI-IR peaks and the secretin-IR peak (Fig. 1, lower panel). Fractions 32-34, $35-42$ and 51-57 were pooled separately to further purify secretin, VIP, and the major PHI-IR form, respectively. Each pool was adsorbed on a $6 \times 1.5 \mathrm{~cm}$ reverse-phase $\mathrm{C} 19$ column, then eluted in concentrated form with $50 \% \mathrm{CH}_{3} \mathrm{CN}$ in $10 \mathrm{mM} \mathrm{HCl}$. After $\mathrm{CH}_{3} \mathrm{CN}$ evaporation and ionic strength adjustment, the eluate from each pool was subjected to a single run chromatography by cation-exchange HPLC on a HR $5 / 5$
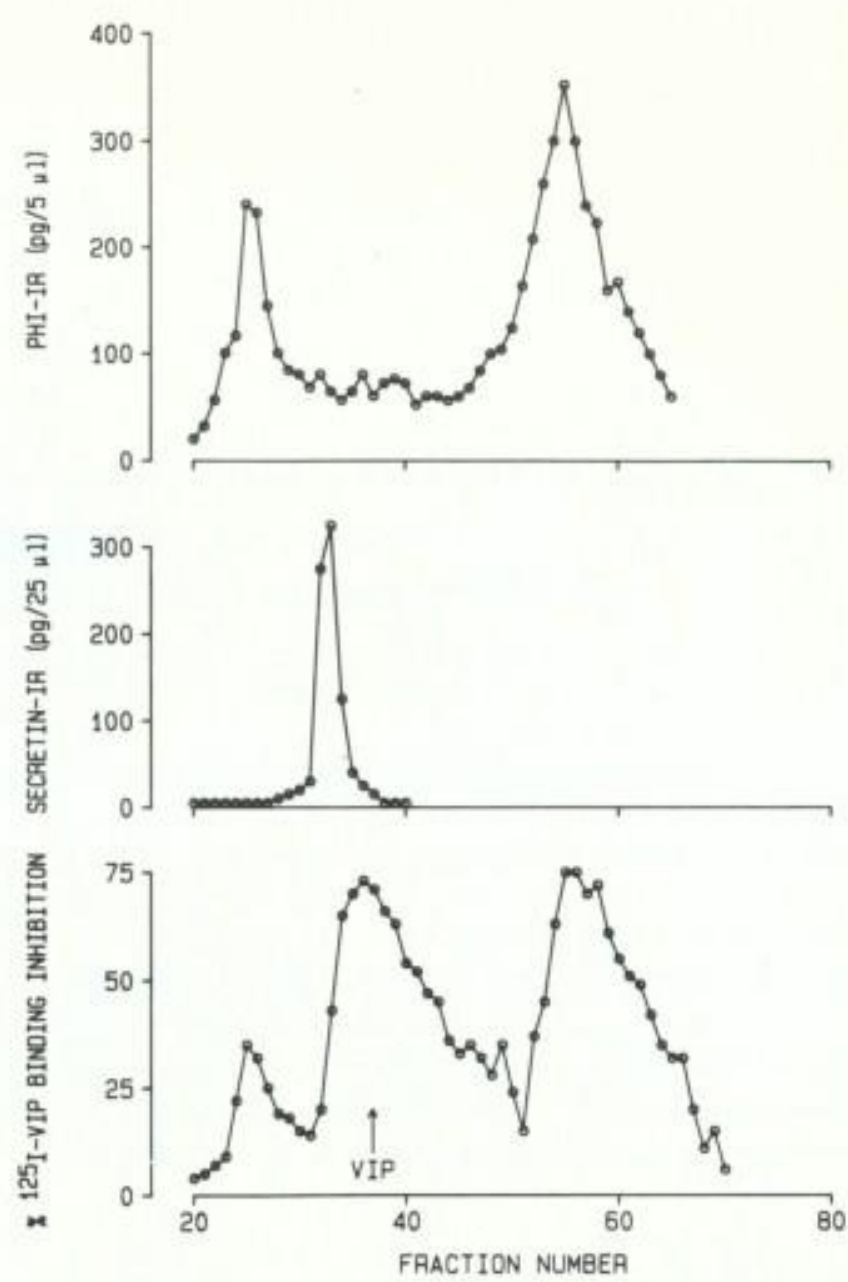

Fig. 1. Chromatography of a small intestinal extract of guinea pig on a Fractogel column (see Materials and Methods). The upper panel shows two peaks of PHI-IR and the middle panel one peak of secretin-IR. The lower panel shows VIP material detected by radioreceptor assay as a single peak (arrow) distinct from the two PHI-IR peaks detected by radioimmunoassay in the upper panel.

Mono S column (Pharmacia, Uppsala, Sweden) as indicated in Figs. 2, 3 and 4 (upper panels): PHI-IR material was eluted with $0.20 \mathrm{M} \mathrm{NaCl}$, secretin-IR with $0.28 \mathrm{M}$ $\mathrm{NaCl}$ and VIP with $0.30 \mathrm{M} \mathrm{NaCl}$. Each relevant peak was pooled and submitted to reverse-phase HPLC on a $25 \times 0.4 \mathrm{~cm}$ Lichrospher 100 RP8-e column (Merck, Darmstadt, F.R.G.). Two runs for VIP and PHI, and 3 runs for secretin were performed with increasingly flatter linear gradients of $\mathrm{CH}_{3} \mathrm{CN}$, as shown in Figs. 2, 3 (middle and lower panels) and 4 (lower panel). Each purified peptide could then be collected as a symmetrical peak in one fraction, and its amount was estimated by absorption at $214 \mathrm{~nm}(1.5 \mu \mathrm{g}$ for secretin) or $280 \mathrm{~nm}$ (20 $\mu \mathrm{g}$ for VIP and $10 \mu \mathrm{g}$ for PHI).

\section{Sequence analysis}

Amino acid sequences were established by Edman degradation in an Applied Biosystems 477 A pulsed liquid-phase sequencer coupled to a $120 \mathrm{~A}$ PTH-amino 

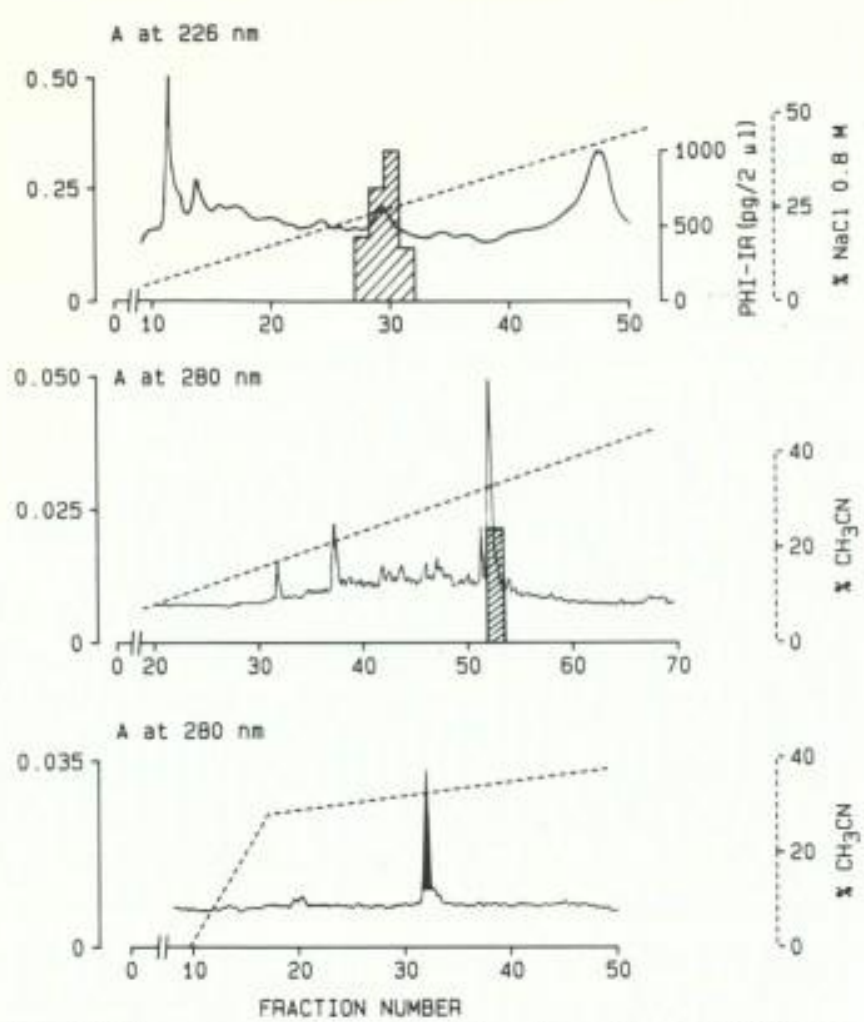

Fig. 2. The upper panel represents the cation-exchange HPLC on a Mono S column of the PHI pool collected after chromatography on Fractogel and reverse-phase HPLC on C18 (see Materials and Methods and Fig. 1, upper panel). The column was equilibrated with 10 $\mathrm{mM} \mathrm{HCl} / 20 \% \mathrm{CH}_{3} \mathrm{CN}$ and eluted at a flow rate of $1 \mathrm{ml} / \mathrm{min}$ with a linear gradient of $0.8 \mathrm{M} \mathrm{NaCl}(0-60 \%$ in $60 \mathrm{~min}$, dashed line). The hatched area represents the PHI-IR material estimated in $\mathrm{pg} \mathrm{PHI-IR/2}$ $\mu \mathrm{l}$. The middle panel shows the results of reverse-phase HPLC on RP8-e of the PHI-IR material collected after Mono S chromatography. The column was equilibrated with $10 \mathrm{mM} \mathrm{HCl} / 3 \% \mathrm{CH}_{3} \mathrm{CN}$ and eluted at a flow rate of $1 \mathrm{ml} / \mathrm{min}$ with a linear gradient of $\mathrm{CH}_{3} \mathrm{CN}$ (3-48\% in $60 \mathrm{~min}$, dashed line). The hatched area represents the PHI material detected by radioreceptor assay (see Materials and Methods). The lower panel shows the results of the second run of reverse-phase HPLC on RP8-e of PHI material collected as shown in the middle panel. The column was equilibrated with $0.1 \%$ trifluoroacetic acid $/ 3 \% \mathrm{CH}_{3} \mathrm{CN}$ and eluted at a flow rate of $1 \mathrm{ml} / \mathrm{min}$ with a linear gradient of $\mathrm{CH}_{3} \mathrm{CN}(28-40 \%$ in $30 \mathrm{~min}$, dashed line). Pure PHI was collected as a symmetrical peak (black area) in one fraction.

acid analyzer (A.B.I., Foster City, CA, U.S.A.). The $\mathrm{C}$-terminus was determined after incubation with yeast carboxypeptidase Y (Boehringer, Mannheim, F.R.G.) for $2 \mathrm{~h}$ at $37^{\circ} \mathrm{C}$ in $0.1 \mathrm{M}$ ammonium acetate buffer $(\mathrm{pH}$ 6.0). The phenylthiocarbamyl (PTC) derivatized amino acids were separated on a Nova-Pak $\mathrm{C} 18$ column $(15 \times$ $0.39 \mathrm{~cm}$ ) from Waters (Milford, MA, U.S.A.) [21].

\section{Results}

Guinea pig VIP, PHI and secretin were purified from $220 \mathrm{~g}$ of whole small intestine using a combination of six to seven chromatographic steps. The two final steps were performed in 1 day. $200 \mathrm{pmol}$ of each peptide were applied on a polybrene filter and sequenced. The sequencer identified unambiguously the 28 amino acids of VIP (Asn- $\mathrm{NH}_{2}$ as Asn), 26 amino acids of PHI and 26 amino acids of secretin. A single time hydrolysis by carboxypeptidase $\mathrm{Y}$ allowed the identification of $\mathrm{C}$ terminal structures.

We confirmed [4] the original sequence of VIP as being: His-Ser-Asp-Ala-Leu-Phe-Thr-Asp-Thr-TyrThr-Arg-Leu-Arg-Lys-Gln-Met-Ala-Met-Lys-Lys-TyrLeu-Asn-Ser-Val-Leu-Asn-NH $\mathrm{NH}_{2}$. By contrast, PHI differed from all other PHIs already described (see Table 1 and Discussion). A second entire run of PHI purification with complete amino acid sequence analysis confirmed this observation. The secretin sequence was established as His-Ser-Asp-Gly-Thr-Phe-Thr-Ser-GluLys-Ser-Arg-Leu-Arg-Asp-Ser-Ala-Arg-Leu-Gln-Arg-
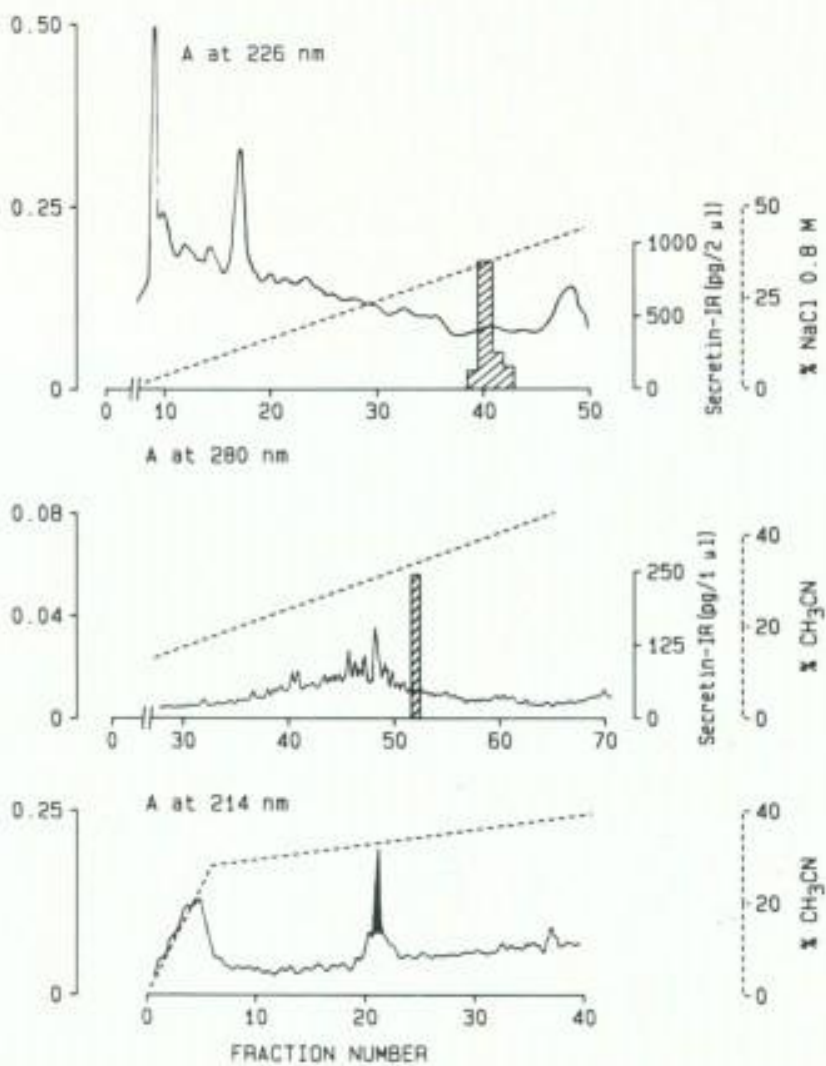

Fig. 3. Upper panel represents cation-exchange HPLC on a Mono S column of the secretin pool collected after chromatography on Fractogel and reverse-phase HPLC on C18 (see Materials and Methods and Fig. 1, middle panel). Conditions were as in Fig. 2, upper panel. The hatched area represents the secretin-IR material estimated in $\mathrm{pg}$ of secretin-IR/2 $\mu \mathrm{l}$. The middle panel represents the first run of reverse-phase HPLC on RP8-e of the secretin-IR material collected after Mono S chromatography. Conditions were as in Fig. 2, middle panel. The hatched area represents the secretin-IR material estimated in $\mathrm{pg}$ secretin-IR/ $/ \mu \mathrm{I}$. The lower panel represents the third and final run of reverse-phase HPLC on RP8-e of secretin-IR material. The column was equilibrated with $0.1 \%$ trifluoroacetic acid $/ 3 \% \mathrm{CH}_{3} \mathrm{CN}$ and eluted at a flow rate of $1 \mathrm{ml} / \mathrm{min}$ with a linear gradient of $\mathrm{CH}_{3} \mathrm{CN}$ (28-40\% in $40 \mathrm{~min}$, dashed line). Pure secretin was collected as a symmetrical peak (black area) in one fraction. 

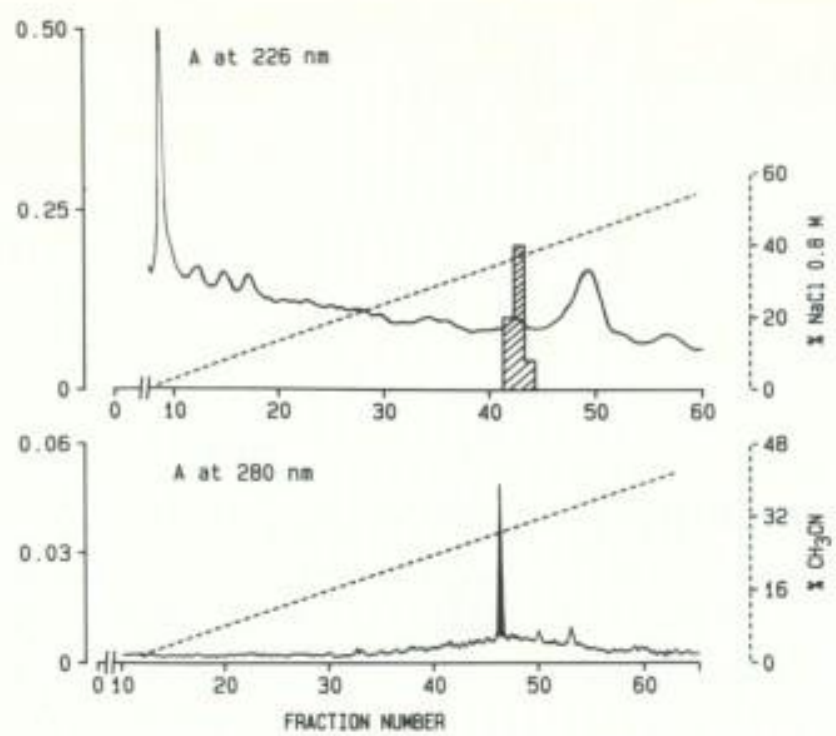

Fig. 4. Upper panel represents cation-exchange HPLC on a Mono S column of the VIP-IR pool collected after chromatography on Fractogel and reverse-phase HPLC on C18 (see Materials and Methods and Fig. 1, lower panel). Conditions were as in Fig. 2, upper panel. The hatched area represents the VIP material detected by radioreceptor assay (see Materials and Methods). The lower panel represents the second and final run (see Materials and Methods) of reverse-phase HPLC on RP8-e of VIP material collected as shown in the upper panel. The column was equilibrated with $0.1 \%$ trifluoroacetic acid/3\% $\mathrm{CH}_{3} \mathrm{CN}$ and eluted at a flow rate of $1 \mathrm{ml} / \mathrm{min}$ with a linear gradient of $\mathrm{CH}_{3} \mathrm{CN}(0-48 \%$ in 60 min dashed line). Pure VIP was collected as a symmetrical peak (black area) in one fraction.

Leu-Leu-Gln-Gly-Leu-Val- $\mathrm{NH}_{2}$ and was identical, therefore, to the porcine and bovine hormone.

\section{Discussion}

The purification of $1.5,10$ and $20 \mu \mathrm{g}$ of, respectively, secretin, PHI and VIP, from $220 \mathrm{~g}$ of guinea pig small intestine was achieved swiftly by a simple procedure derived from that we used to purify rat PHI [11]. Two factors were of importance: (a) the use of a Fractogel column that rapidly separated the three peptides at an early step of purification: to succeed, this separation of peptides having a similar molecular weight obviously depended on ill-defined interactions with the column matrix; and (b) a rapid radioreceptor assay was utilized to detect VIP and PHI as soon as possible, in order to accelerate the purification procedure and minimize the hazard of peptide adsorption on polypropylene tubes.

The sequence of guinea pig VIP was confirmed [4], with Leu, Thr, Met and Val, in positions 5, 9, 19 and 26, respectively, and clearly differed from those of other mammalian VIPs that are all identical (see Introduction), in line with the peculiar evolution of this mammalian class of hystricomorphs.

The radioimmunoassay profile of PHI-IR after chromatography on Fractogel of the guinea pig intestinal extract, differed from that of rat intestinal PHI-IR in that two peaks only were separated from the guinea pig extract whereas three peaks were segregated in the rat $[11,22]$. By analogy with the situation in the rat intestinal extract, it is conceivable that the first peak of PHI-IR in guinea pig corresponded to a large $\mathrm{PHI}$ form such as PHI C-terminally extended by most of a connecting peptide between PHI and VIP $[22,23]$ but we did not have enough material to pursue the purification of this form of PHI. The second peak of guinea pig PHI-IR proved to be a regular (1-27) amide form. Besides, a major PHI-IR peak identified as PHI (1-27)Gly in rat intestine, and eluting in intermediary position from Fractogel [11], was virtually absent in guinea pig intestinal extracts (Fig. 1, upper panel), suggesting a higher peptidylglycine $\alpha$-amidating monooxygenase activity in guinea pig than in rat small intestine [24].

Like guinea pig VIP, the guinea pig PHI we sequenced differed from other known mammalian PHI sequences (see Table I). The presence of Arg instead of Lys in position 20 could possibly reflect a simple transition of the second base in corresponding codons $(\mathrm{A} \rightarrow$ G). Such a change is unlikely to profoundly alter the biological activity of guinea pig PHI as compared to other PHIs.

At variance with both neuropeptides, the sequence of guinea pig secretin was identical to the corresponding bovine and porcine hormone. Thus, as high affinity

TABLE 1

Comparison of the amino acid sequence of four mammalian PHI and human peptide histidine-methioninamide (PHM)

\begin{tabular}{|c|c|c|c|c|c|c|}
\hline Species & 1 & 5 & 10 & 15 & 20 & 25 \\
\hline Guinea pig & \multirow{2}{*}{\multicolumn{6}{|c|}{$\begin{array}{l}\text { HADGVFTSDYSRLLGQLSARKYLESLI * } \\
\text { HADGVFTSDYSRLLGQLSAKKYLESLI * }\end{array}$}} \\
\hline Bovine & & & & & & \\
\hline Porcine & \multicolumn{6}{|c|}{ HADGVFTSDFSRLLGQLSAKKYLESLI * } \\
\hline Rat & \multicolumn{6}{|c|}{ HADGVFTSDYSRLLGQISAKKYLESLI * } \\
\hline Human & \multicolumn{6}{|c|}{ HADGVFTSDESKLLGQLSAKKKYLESLE * } \\
\hline
\end{tabular}

- Represents $\mathrm{NH}_{2}$.

Differences with guinea pig $\mathrm{PHI}$ are underlined. 
receptors for porcine secretin are present in guinea pig pancreatic acinar cells and gastric chief cells $[25,26]$, these receptors are likely to be physiologically relevant in the control of secretory processes in the pancreas and stomach of guinea pig.

\section{Acknowledgments}

Aided by grant 3.4571 .85 from the Fund for Medical Scientific Research (Belgium), a Concerted Research Action from the Ministry of Scientific Politics (Belgium), and Grant STJ-000-1-B from the E.E.C. A. Cauvin and D. Gossen are recipients of a predoctoral fellowship from I.R.S.I.A. (Belgium).

\section{References}

1 Mutt, V. and Said, S.I. (1974) Eur. J. Biochem. 42, 581-589.

2 Carlquist, M., Mutt, V. and Jörnvall, H. (1979) FEBS Lett. 108, 457-460.

3 Wang, S.C., Du, B.H., Eng, J., Chang, M., Hulmes, J.D., Pan, Y.-C.E. and Yalow, R.S. (1985) Life Sci. 37, 979-983.

4 Du, B.H., Eng. J., Hulmes, J.D., Chang, M., Pan, Y.-C.E. and Yalow, R.S. (1985) Biochem. Biophys. Res. Commun. 128, 10931098.

5 Dimaline, R., Reeve, J.R., Shively, J.E. and Hawke, D. (1984) Peptides 5, 183-187.

6 Nishizawa, M., Hayakawa, Y., Yanaihara, N. and Okamoto, H. (1985) FEBS Lett. 183, 55-59.

7 Eng, J. and Yalow, R.S. (1989) Methods Enzymol. 168, 302-308.

8 Carlquist, M., Mc Donald, T.J., Go, V.L.W., Bataille, D., Johansson, C. and Mutt, V. (1982) Horm. Metab. Res. 14, 28-29.

9 Tatemoto, K. and Mutt, V. (1981) Proc. Natl. Acad. Sci. USA 78. 6603-6607.
10 Carlquist, M., Kaiser, R., Tatemoto, K., Jörnvall, H. and Mutt, V. (1984) Eur. J. Biochem. 144, 243-247.

11 Cauvin, A., Vandermeers, A., Vandermeers-Piret, M.C., Rathé, J., Robberecht, P, and Christophe, J. (1989) Endocrinology 125, 1296-1302.

12 Itoh, N., Obata, K., Yanaihara, N. and Okamoto, H. (1983) Nature 304, 547-549.

13 Bishop, A.E., Polak, J.M., Yiangou, Y., Christophides, N.D. and Bloom, S.R. (1984) Peptides 5, 255-259.

14 Robberecht, P., Chatelain, P., Waelbroeck, M. and Christophe, J. (1982) in Vasoactive Intestinal Peptide (Said, S.I., ed.), pp. 323332, Raven Press, New York.

15 Mutt, V., Jorpes, J.E. and Magnusson, S. (1970) Eur. J. Biochem. 15, 513-519.

16 Carlquist, M., Jörnvall, H. and Mutt, V. (1981) FEBS Lett. 127, $71-74$.

17 Shinomura, Y., Eng, J. and Yalow, R.S. (1987) Life. Sci. 41, 1243-1248.

18 Gossen, D., Vandermeers, A., Vandermeers-Piret, M.C., Rathé, J., Cauvin, A., Robberecht, P. and Christophe, J. (1989) Biochem. Biophys. Res. Commun. 160, 862-867.

19 Carlquist, M., Jörnvall, H., Forssmann, W.G., Thulin, L., Johansson, C. and Mutt, V. (1985) IRSC Med. Sci. 13, 217-218.

20 Robberecht, P., Coy, D.H., De Neef, P., Camus, J.C., Cauvin, A., Walbroeck, M. and Christophe, J. (1986) Eur. J. Biochem. 159, $45-49$.

21 Hayashi, R. (1972) Methods Enzymol. 47, 84-93.

22 Cauvin, A., Vandermeers, A., Vandermeers-Piret, M.C., Robberecht, P. and Christophe, J. (1989) Endocrinology in press.

23 Dimaline, R., Young. J., Thwaites, D.T., Lee, C.M., Shuttleworth, T.J. and Thorndyke, M.C. (1987) Biochem. Biophys. Acta 930. 97-100.

24 Eipper, B.A., Myers, A.C. and Mains, R.E. (1985) Endocrinology 116, 2497-2504.

25 Zhou, Z.-C., Gardner, J.D. and Jensen, R.T. (1987) Peptides 8, 633-637.

26 Sutliff, V.E., Raufman, J.P., Jensen, R.T. and Gardner, J.D. (1986) Am. J. Physiol. 251, G96-G102. 